\title{
Legal Valences of Public-Private Partnership in the Republic of Moldova as an Economic Tool for Innovative Directions of Development
}

\author{
Irina Calugareanu ${ }^{1,}$ \\ ${ }^{1}$ Academy of Economic Studies of Moldova, Chisinau, Republic of Moldova \\ Correspondence: Irina Calugareanu, Academy of Economic Studies of Moldova, Chisinau, Republic of Moldova.
}

Received: November 5, 2020

Accepted: November 25, 2020

Available online: December 18, 2020

doi:10.11114/ijsss.v9i1.5110

URL: https://doi.org/10.11114/ijsss.v9i1.5110

\begin{abstract}
The current economic situation leads to significant changes in the social sector of society. Formerly owned by the state, the infrastructure objects are transferred to private companies, the state reserving the right to regulate and monitor the subsequent activities of these objects. The public-private partnership is based on the cooperation between the public partner and the private partner to increase the efficiency of the public patrimony, each partner assuming concrete risks, innovations, and responsibilities.

The Republic of Moldova development required the introduction of innovative management tools for implementing state and regional development strategies, such as the new format of specific programs, strategies for developing regional clusters, the introduction of public-private partnership principles. Governments understood that PPPs could help overcome the situation in the Republic of Moldova when medium and long-term financing sources with a maturity of 3 years are virtually inaccessible within the existing banking system. This situation, combined with a constant lack of financial resources in the budget, suggests that the initiation of the PPP is an alternative tool to further the country's infrastructure development.

The article reviews the local legal valences on the public-private partnerships as an economic tool for innovative directions of development and the main weaknesses of the Republic of Moldova framework.
\end{abstract}

Keywords: economy, models, public-private partnership, state, private environment, implementation, company, development.

\section{Introduction}

During the years of economic reforms, there was a change in priorities regarding income distribution, social development, provision of social services, and the functioning of the social infrastructure sector. The elements of market systems and institutions are the results of the socio-economic system reorganization from the principle of centralized administrative regulation to a mixed form of management, and in the last decade to regulate market relations, but significantly increased the role of state institutions.

As part of the administrative-fiscal reform, the public-private partnership policy (hereinafter PPP) is also implemented in the Republic of Moldova. The Government of the Republic of Moldova has played important roles in promoting the PPP system and is making efforts to encourage the participation, competitiveness, and transparency of this model of relationship. Nevertheless, during the development of PPP relations, several problems were noted regarding the implementation of PPP projects, including deficiencies in the legal framework, lack of clarity and transparency in the procedures for selecting the private partner, elaboration of contractual conditions, the control mechanism regarding the execution of the project and its compliance, as well as other elements of the formation and implementation of these models of projects.

The current stage of socio-economic development of the Republic of Moldova is characterized by the low efficiency of the business-government relations system, which still does not allow the effective implementation of the interaction functions of subjects and negatively affects the solution of many economic and social problems of society, which was observed in the context of the current pandemic situation. However, the interaction between government and business in the context of the infrastructure projects development should be a key factor in the sustainable development of the country. 
Furthermore, it should be considered that attracting investments in the infrastructure is associated with several difficulties, because it needs large capital investment and has little value for money, which contradicts the Moldovan, established perception rates of return. This is due to the fact that the Republic of Moldova private business was formed in the process of state and municipal enterprises privatization. We could consider the beginning of privatization as the starting point for the formation and further development of the public-private partnership. In connection with that, all the unrealized tasks of the government to establish an "effective segment of ownership" directly impacted the ways and methods of doing business in the Republic of Moldova. The trends that developed during the privatization process for the redistribution of share ownership acquire a permanent and strongly conflicting character in modern conditions, which negatively affects the financial and economic activity, as well as the attractiveness of investments for domestic companies. This is explained, in our opinion, by a transitional, non-compliant structure of share capital.

This is expressed in such deformations of the business domains such as tax evasion, payment of too low wages to employees, breaches of competitive business conditions, etc. Continuation of such negative factors influence over a long period relates to the lack of economic instruments that ensuring the formation of an effective business environment. It should also be noted that the main negative result of privatization is due to the inefficiency of the regulatory framework governing the activity of effective post-privatization control.

Because, the most important role in the formation of the PPP has institutional and state support regarding this process, a significant place in our study is given to the Republic of Moldova policy review in the field of building the foundations of public-private partnerships.

\section{Method}

The research methodology has a preponderant normative character and consists of theoretical principles of the concept and process of public-private partnership, methods and techniques of data selection (information-factual support), methods and techniques of data processing, logical analysis of generalization procedures, and the theory systematization.

\section{Results}

\subsection{Development of the Legal Framework of Public-Private Partnerships in the Republic of Moldova}

Measures for the creation of a normative framework favorable to the development of PPPs began during the years 1990-1992 by liberalizing the public sector, being adopted several Lows (the Law on Property, 1991, the Law on Privatization,1991; the Law on Cooperation, 1992). The legislative foundations of the public-private partnership began to take shape when the country's Parliament adopted the Law on Concessions (1995), which is currently the main model and the most popular form of PPP globally. The nominated law was initially provided for regulating the relations of natural resources concession and was only a rudimentary beginning in the process of evolution of the Republic of Moldova PPP. The process continued, with the adoption of new sectorial regulations (the Law on Leasing, 1996; the Law on Natural Resources, 1997).

The development of public-private partnerships in the Republic of Moldova, as a separate concept, began in 2007. Until 2008 , there were no special laws on public-private partnerships. PPP projects were implemented on a general legislative basis, especially in the following areas: communal services; gas and electricity supply, transport infrastructure, healthcare. Therefore, to contribute to private investment for public interest projects attraction, to increase the efficiency and quality of services, public works, and other activities of public interest, and to use efficiently public assets and public finance, in 2008, was adopted the Law on public-private partnership, and defined the institutional framework responsible for the development and functioning the PPP system. For the Republic of Moldova, international legal assumptions and commitments, which formed the basis of the PPP development stages, were: the Green Paper on public-private partnerships, adopted by the European Commission in 2004 and international agreements, such as the Memorandum of Economic and Financial Policies, signed between the Government of the Republic of Moldova and the International Monetary Fund and Directives of the European Parliament and the European Council on coordination the public-private contracts (Green Paper, 2004; Memorandum, 2007; Directive 17/EC, 2004, Directive 18/EC, 2004).

The public-private partnership is expected to provide superior performance to key projects and increase the capacity for innovation and competitiveness in sectors with employment/growth potential.

In this regard, the main objective of public authorities in the implementation of a public-private partnership was the creation of a greater added value for the provision of public services. Another objective of the state within the public-private partnership was the transfer of risks to the private investor, related to the construction, design, financing, and planning of the infrastructure objects, as well as its subsequent operation.

The main goal of the private sector is to obtain maximum profit from projects implemented in cooperation with state and municipal authorities (Yescombe,\&Farquharson, 2018, 56-57). Therefore, the objectives of the state and the 
business environment were using PPPs as an innovative system for economic development as is shown in Table 1.

Table 1. The objectives of the state and the business environment when using the PPP system

\begin{tabular}{|c|c|c|}
\hline Nb. & State objectives & Business environment objectives \\
\hline 1 & $\begin{array}{l}\text { Increasing the living standard of the population, } \\
\text { promoting the development of "human capital". }\end{array}$ & $\begin{array}{l}\text { free movement of capital, } \mathrm{p} \\
\text { accessible. }\end{array}$ \\
\hline 2 & ing structural constraints on economic & Attracting budgetary funds for project implementation. \\
\hline 3 & $\begin{array}{l}\text { Promoting the competitiveness of national } \\
\text { companies, strengthening positions in domestic } \\
\text { and foreign markets. }\end{array}$ & it credits allocated by financial \\
\hline 4 & $\begin{array}{l}\text { Socio-economic development } \quad \text { of } \\
\text { regions/counties. }\end{array}$ & $\begin{array}{l}\text { Facilitating the relations with government authorities, through state } \\
\text { participation in the project ( on getting licenses, permits, supervision } \\
\text { notices). }\end{array}$ \\
\hline 5 & $\begin{array}{l}\text { Rational integration into the global and } \\
\text { community economy. }\end{array}$ & $\begin{array}{l}\text { Increasing the status of the project through state participation. Creating a } \\
\text { positive image of the company. }\end{array}$ \\
\hline
\end{tabular}

Source: Developed by the author based on (Puie, 2011, 20-21)

The goal of PPP is to combine the best parts of the public and private sector for mutual benefit, and the diversity of forms and models used in the public-private partnership makes it a universal mechanism for solving long-term goals, from infrastructure development to the adaptation of new perspective technologies and innovative methods of management. To ensure the participation of the private sector in the implementation of socially important infrastructure projects, the state administration must strike a balance between risks and benefits acceptable to both parties.

3.2 Legal Provisions that Outline the Normative Content of the Law on Public-Private Partnership in the Republic of Moldova

\section{Partners requirement and PPP principles}

There are various classifications of partnerships between the state and the private sector In the literature (Delmon, 2011; Puie, 2011; Yescombe\&Farquharson, 2018), Whereby, are determined the rights and responsibilities transmitted by the state to the private sector, while the benefits of the parties depend on the distribution of risks and the choice of the payment mechanism by the state, to the private sector. Next, we will discuss the essential legal provisions of the Republic of Moldova PPP Low, that outline the normative content on public-private partnerships, in particular, the models and control of the public-private partnership realization (Law, 2018).

To ensure equal treatment, private sector tenderers in the PPP process on certain infrastructure objects, services, works, the positive obligation is required according to Art. 4: "to ensure all tenderers equal treatment within any element or any stage of the selection procedure of the private partner. In all cases, the criteria for selecting the private partner will be clear and non-discriminatory". At the same time, public authorities should be impartial and non-discriminatory to the subjects involved in PPPs.

The principle of equal treatment requires public authorities to establish clear and non-discriminatory criteria for private partner selection. To ensure substantial and non-formal equal treatment, any technical requirements, established by the public partner must guarantee equal access for all partners (potential tenderers) at all stages of the PPP procedure.

The principle of equal treatment is a fundamental one for ensuring effective competition in the process of private partner selection in the market economy. For these reasons, Art.8 outlines the content of the competition assurance principle, which generates obligations for both parties the public partner and the potential tenderers (Law, 2008). In this regard, the public partner is required not to limit in any way the competition between tenderers, moreover, to ensure the legal-economic paradigm, the public partner has a legal and effective obligation to ensure real competition in determining the number of bidders invited to participate in the PPP. In the procedure for selecting the private partner, it is also prohibited the simultaneous and independent participation of legal entities and their subsidiaries as tenderers. We would like to point out that the public-private partnership regarding the concession of Chisinau International Airport corresponds to this principle with a rhetorical question, considering that substantially, the offer was submitted by interdependent subjects.

Another fundamental principle characteristic of the market economy and in general of the economic freedom that has been regulated in the Law is the principle of contractual freedom. In essence, freedom of contract implies the freedom to conclude, or not contracts, to choose contractual partners, and to determine the content of the contract. In the matter of PPPs, contractual freedom must be understood in the sense of conditioned freedom by social life and legal norms. 
Thus, Art. 9, in the enunciated sense stipulates that "unless the law provides otherwise, the parties of the public-private partnership are entitled to freely determine their rights and obligations established by contract", moreover, the contractual freedom requires the good faith of the subjects involved in the PPP stages (Law, 2008). In particular, contractual freedom must be understood in terms of contractual solidarity and the social function of PPPs. Therefore in close correlation with the contractual freedom principle is the cooperation principle which obliges public authorities as a public partner to assist the private partner in administrative and other legal procedures for obtaining permits, authorizations, and other documents related to PPP, whether they are provided by law, or by contract. At the same time, not to the detriment of contractual freedom, the legislation expressly establishes what the clauses of a PPP contract must contain.

From a conceptual point of view, PPP is to be carried out taking into account two other legal paradigms such as the principle of proportionality and the principle of balance. In essence, proportionality assumes a balance between the public and the private partner's interest. Thus, the public partner has the right to undertake those official measures or to request the partner to undertake certain actions that are necessary and related to the object of the public-private partnership; are comparable to the importance of the objective of the public-private partnership taking into account both purpose and consequences; the least will restrict or negatively affect the private partner. We must mention that the engineering of proportionality requires the public authority to perform analyzes and assessments of the factual components that characterize the contrary interests taking into account the balance principle. In essence, proportionality itself, in the context of PPPs, implies that any measure or action cannot adversely affect the private partner and cannot be disproportionate to the legitimate aim pursued by the public partner. For the violation of this principle, the private partner is open to legal redress for actual damages and lost income.

The PPP's principles constellation also includes the balance rule, which essentially assumes the rights and obligations as well as the benefits of the public and private partners which have to be found and not just based on the level of effective and efficient balance. Also according to the logic of this principle, the distribution of risks between partners must be carried out following the contractual clauses of the PPP. For this reason, at the contract conclusion, it is very important to be nominated for each type of risk and their distribution between partners. To accomplish the mentioned legal task is required a deeper investigation at the pre-contractual stage to identify approximately and within the legal limits the typology of PPP risks.

In summary, we would like to mention that the analyzed principles indicate and offer us the possibility to conclude about their interdependent connection and organizational system of PPP principles that should be the source of inspiration for risk management of infrastructure projects in the Republic of Moldova.

\section{Object, models of realization and control of the PPP within the Republic of Moldova:}

Art. 17 underline "the public-private partnership is based on the cooperation between the public partner and the private partner to increase the efficiency of the public patrimony, each partner assuming concrete risks and responsibilities". This legal provision emphasizes two fundamental elements of the PPP: the first is the cooperation between the public and the private partner which implicitly includes the principle of contractual freedom, the risks, and specific responsibilities for each partner. The second element lies in the purpose of the PPP, which is to increase the efficiency of public assets. The legal notion of efficiency of the public patrimony, according to the way it is formulated in Art. 17 does not reflect, in our opinion, an essential element that characterizes the organization and planning of investments, namely: the legislator focuses the PPP object only on the side of the public partner's interests, but the efficiency of public assets must not exclude the private partner's profit interest. Or the entrepreneurial activity and its organization are inconceivable from an economic point of view in the absence of predictable and sustainable profits. Art. 17, section 1 wording denotes a conception of legal intervention in which, in our opinion, the public interest is disproportionate. For these reasons, the legislator has to review the wording of Art. 17, of 1 in which, after "increasing the efficiency of the public patrimony", the interest of the private partner can be found in a fair balance with the interest of the public partner (Law, 2008).

The PPP object according to Art.17 section 2 is outlined and could be "any goods, including those attributed to the public domain, work, public service or function exercised by the public partner, except for those expressly prohibited by law". At the same time, the aforementioned legal norm allows the establishment of exceptions regarding the object of PPP. Thus, in our opinion, some public goods or services that are elements of fundamental national strategic importance cannot be the object of the PPP: some military enterprises, fiscal services, public services for population documentation, civil status, etc. The elements of the PPP object can be those of the existing infrastructure and public utility services, but we would like to mention that there are possibilities to create new public utility services and even new infrastructures through the PPP.

The public-private partnership is realized through the following models according to art. 18., section 1, (Law, 2008): 
a) out works/ services provision contract;

b) fiduciary administration contract;

c) tenancy/lease contract;

d) concession contract;

e) joint ventures or civil/commercial companies with fully or partially state capital;

f) other contractual models that are not prohibited by law, by the public-private partnership contract, or by the model's combination established above.

The framework of property concession in the Republic of Moldova is regulated by the Law on concessions and service concessions building nb. 121 (Law, 2018), but from the enunciated legal norm we deduce that the PPP models are not exhaustive, and the public and private partner can choose under the contractual freedom principle - Art. 9, some contractual models that are not provided by the legislation in force, or complex contracts by combining the typical models regulated in the normative framework. The contractual freedom establishing the PPP relationship has to be achieved on the contest basis because the contest ensures competition and transparency and consequently PPP efficiency of public assets, increased investment, and consumer protection, following the Art. 18 section 9 (Law, 2008). Also, each of the PPPs models has advantages and disadvantages, so the structure of the public-private partnership project must be coordinated with the priority needs of the sector and the project aims.

Depending on the level of involvement of the private partner, PPP contracts are performed in the following ways:

a) design-construction-operation, where the construction and operation of the PPP object are transferred to the private partner for a maximum of 50 years. The public-private partnership project can be fully funded by the private partner. Upon expiration of the contract concluded with the public partner, the object of the public-private partnership is transferred free of charge to the public partner in good condition, functional, and free from any task or obligation;

b) construction-operation-renewal, where the private partner assumes the financing of the object construction of the public-private partnership, as well as all its maintenance costs for a maximum period of 50 years. Following the legislation in force, the private partner is allowed to collect the appropriate tariffs for the usage of the public good with the determined period. Upon expiration of the contract, the object of the public-private partnership is transferred free of charge to the public partner in good condition, functional, and free from any task or obligation;

c) construction-operation-transfer, where the private partner assumes the construction, financing, operation, and maintenance of a public good. The investor is allowed to charge usage fees to recover his investment and cover his maintenance costs, as well as to make a reasonable profit. At the end of the contract, the public good is transferred free of charge to the public authority in good condition and free from any task or obligation;

d) construction-transfer-operation, through which the private partner assumes the construction of an object that is transferred to the public partner ownership immediately after the completion of the construction, and the public partner, transmits it for use to the private partner;

e) lease-development-operation, where the private partner obtains in temporary use or the possession and temporary use a public good, committing itself to pay in installments its price during a period that will not exceed 50 years. Unless otherwise provided in the contract, the public partner acquires the right to obtain income from the services provided by the private partner, and at the end of the contract, the public good is transferred to the public authority in good condition and free from any burden or obligation;

f) renovation-operation-transfer, where the public good is transferred to the private partner, which must renovate, operate, and maintain the public good for a period that cannot exceed 50 years.

The list of modalities provided by law is not exhaustive, there could be established other ways of performing PPP contracts if they are not expressly prohibited by the law. As can be seen, the characteristic of all PPP models is the 50 -years of the PPP contract. But we believe that the figure of 50 years should be replaced by the term 99 years as it is used in the laws of Occident states, because they are more attractive, ensure the planning and organization of long-term investment decisions. Conducting documentary research, we identify what was the basis of the 50 years choice. In the sectorial laws, especially the Civil Code, the terms of the contracts are expressly imposed, respectively if it is chosen as a way to achieve the PPP - a lease, then according to the Civil Code, the PPP contract will have a maximum duration of 30 years. Art. 1291. Term of a lease (1) The term of the lease shall be fixed by the Contracting Parties, but shall not be less than 1 year and not more than 30 years. (2) When leasing agricultural lands to plant perennial plantations, the term of the lease shall be at least 25 years, if no other term is provided in the contract (Civil Code, 2002).

Also, an important feature of the PPP contractual models and the ways of their realization refers to the intellectual property right created in the process of PPP implementation. It seems that the legislator chose the principle of contractual freedom on how to acquire intellectual property rights. Therefore, the public and private partners are those who establish the pattern and the legal regime of the property right over the intellectual product according to the art. 21 "the property right over the intellectual product created in the process of PPP implementation is acquired in the way 
provided by the contract".

The control of the PPP implementation is performed by the public partner through annual audits on the PPP implementation. These audits involve independent auditors and are not excluded from the control performed by the authority bodies in charge of the external public audit. Any derogations from the PPP shall be settled amicably within a period agreed by the parties. Depending on the breaches of contractual obligations, the parties are entitled to terminate the contract. Any dispute arising from the performance of the PPP contract shall be settled amicably but the parties are entitled to refer it to the mediator or arbitrator.

To guarantee the execution of the PPP contract, the parties are obliged to provide guarantees (Law, 2008). At the same time, the private partner is not entitled to alienate, pledge, or affect the object of the PPP without the approval of the public partner. The contractual parties may amend the contractual conditions to ensure the economic interests of the private partner if there are adopted normative acts that substantially worsen the situation of the private partner that he would not have concluded the contract under the existing conditions. This situation is called the hardship clause.

\section{Discussion}

In summary, the basic legal framework governing the bases of PPPs in the Republic of Moldova is relatively stable, corresponds to international standards, is predictable, and ensures transparency and security of investment legal relations. However, the weaknesses in the implementation of the PPP regulatory framework are due to human resources who are not trained sufficiently and do not have experience in this domain. In the same context, the PPP implementation is fed by the deficiency of political factors, the economic culture of the population, and business in general, including the lack of perception of the role and purpose of PPP in a viable market economy by the majority of politics.

Corruption factors are generated by multi-meaning provisions that give the public authority the possibility to interpret the law in a distorted way to the detriment of the public interest. The non-transparent procedure for forming the PPP Evaluation Commission in particular non-involvement in the PPP Assessment Commission the civil society and the academic environment to ensure that control of civil society in the context of starting and conducting the PPP procedures. The lack of an Appeal Commission with clearly established responsibilities also makes difficult the efficient working of the PPP process.

All the above-mentioned weaknesses must be removed by amending the primary and secondary legal framework of the Republic of Moldova governing PPP relations. We would like to note that in essence and conclusion, the basic problem faced by the relevant public authorities was the lack of knowledge and practical skills for the successful implementation of the regulatory framework on public-private partnerships.

\section{Acknowledgements}

I would like to thank associate prof., PhD., Pisaniuc Maia for involving in the State Program"Innovative business configuration in the context of regional competition", nb. 20.800020807.42.

\section{References}

Civil Code. (2002). Retrieved from Lex website https://www.legis.md/cautare/getResults?doc_id=112573\&lang=ro

Delmon, J. (2011). Public-Private Partnership Projects in Infrastructure: An Essential Guide for Policy Makers. New York: Cambridge university press.

Directive 17/EC (2004). Coordinating the procurement procedures of entities operating in the water, energy, transport, and postal services sectors. Retrieved from https://eur-lex.europa.eu/legal-content/EN/TXT/HTML/?uri=CELEX:32004L0017\&from=EN

Directive 18/EC. (2004). Coordination of procedures for the award of public works contracts, public supply contracts and public service contracts. Retrieved from https://eur-lex.europa.eu/legal-content/EN/TXT/HTML/?uri=CELEX:32004L0018\&from=ro

Green Paper. (2004). Public-private partnerships and Community law on public contracts and concessions. Retrieved from https://op.europa.eu/en/publication-detail/-/publication/94a3f02f-ab6a-47ed-b6b2-7de60830625e/language-en

Law (1991). On privatization, $n b .627$. Retrieved from http://www.law-moldova.com/laws/rom/o_privatizatsii_ro.txt

Law. (1991). Property $n b .459$. Retrieved from https://www.legis.md/cautare/getResults?doc_id=85737\&lang=ro

Law. (1992). On cooperation $n b$. 864. Retrieved from https://www.legis.md/cautare/getResults?doc_id=64443\&lang=ro

Law. (1995). On concessions $n b .534$. Retrieved from https://www.legis.md/cautare/getResults?doc_id=109429\&lang=ro

Law. (1996). On Leasing. nb. 49-50. Retrieved from

http://aita.md/Fisiere/Legi_ale_RM/Legea\%20cu\%20privire\%20la\%20leasing.pdf 
Law. (1997). On Natural Resources. $n b .1002$. Retrieved from https://www.legis.md/cautare/getResults?doc_id=109389\&lang=ro

Law. (2008). Public-private partnership nb. 179. Retrieved from http://lex.justice.md/md/328990/

Law. (2018). Concessions and service concessions building $n b$. 121 . Retrieved from http://lex.justice.md/md/376821\%20/

Memorandum. (2007). Economic and Financial Policies. Retrieved from https://www.imf.org/external/np/loi/2007/gmb/082007.pdf

Puie, O. (2011). Parteneriatul public-privat. București: Universul Juridic

Yescombe, E. R., \& Farquharson, E. (2018). Public-Private Partnerships for Infrastructure (2nd ed.). UK: Butterworth-Heinemann. https://doi.org/10.1016/B978-0-08-100766-2.00002-4

\section{Copyrights}

Copyright for this article is retained by the author(s), with first publication rights granted to the journal.

This is an open-access article distributed under the terms and conditions of the Creative Commons Attribution license which permits unrestricted use, distribution, and reproduction in any medium, provided the original work is properly cited. 